Sains Malaysiana 49(1)(2020): 155-160

http://dx.doi.org/10.17576/jsm-2020-4901-19

\title{
Prediction of HIV Mortality in Thailand using Three Data Sets from the National AIDS Program Database
}

(Anggaran Kematian HIV di Thailand menggunakan Tiga Set Data daripada Pangkalan Data Program AIDS Kebangsaan)

\author{
Hiwot D. Tulu*, Apiradee Lim, Arinda Ma-A-Lee, Kanitta Bundhamcharoen' \& Nuttapat Makka
}

\section{ABSTRACT}

HIV continues to hinder the growth and development of a country and identifying the mortality rate will help to address this problem. Therefore, we sought to examine HIV mortality in Thailand in the years 2014 and 2015. A retrospective study was conducted to investigate HIV mortality in all regions of Thailand. For the reliability of this study, the data were drawn from two main sources, Bureau of Registration and Administration (BORA) and the National Health Security Office (NHSO) of Thailand. A total of 23,243 deaths were recorded in years 2014 and 2015. Negative binomial regression was used to predict and compare HIV mortality rates by year, age group and gender. The overall HIV mortality accounted for 2.6\% of all reported deaths, representing 18.3 deaths per 100,000 populations. Among HIV deaths, 91\% of them participated in the National AIDS Program (NAP) and 56\% of them received Antiretroviral Therapy (ART). There was statistically significant effect, with males having a higher death rates than females. Despite the relevance of reduction of HIV mortality in Thailand, our study clearly shows that HIV mortality in Thailand is much dependent on age and gender. Thus, we suggest continued effort is needed to address gender and age difference.

Keywords: HIV mortality; National AIDS Program; negative binomial; prediction

\section{ABSTRAK}

HIV terus menghalang pertumbuhan dan perkembangan negara dan mengenal pasti kadar kematian akan membantu menangani masalah ini. Oleh itu, kami berusaha meneliti kadar kematian akibat HIV di Thailand pada tahun 2014 dan 2015. Kajian retrospektif telah dijalankan untuk mengkaji kadar kematian HIV di semua rantau di Thailand. Untuk kebolehpercayaan kajian ini, data tersebut diambil daripada dua sumber utama, Biro Pendaftaran dan Pentadbiran (BORA) serta Pejabat Keselamatan Kesihatan Kebangsaan (NHSO) Thailand. Sebanyak 23,243 kematian dicatatkan pada tahun 2014 dan 2015. Regresi binomial negatif digunakan untuk meramalkan dan membandingkan kadar kematian HIV mengikut tahun, kumpulan umur dan jantina. Keseluruhan kematian HIV menyumbang 2.6\% daripada semua kematian yang dilaporkan, mewakili 18.3 kematian bagi setiap 100,000 penduduk. Antara kematian akibat HIV, 91\% daripadanya telah menyertai Program AIDS Kebangsaan (NAP) dan 56\% daripadanya menerima Terapi Antiretroviral (ART). Terdapat kesan yang signifikan secara statistik, dengan lelaki mempunyai kadar kematian lebih tinggi berbanding wanita. Walaupun terdapat relevan pengurangan kematian HIV di Thailand, kajian kami dengan jelas menunjukkan bahawa kematian HIV di Thailand sangat bergantung kepada umur dan jantina. Oleh itu, kami mencadangkan usaha berterusan diperlukan untuk menangani perbezaan jantina.

Kata kunci: Binomial Negatif; kematian HIV; Program AIDS Kebangsaan; ramalan

\section{INTRODUCTION}

It is widely viewed that mortality negatively affects the development of a country and causes a burden to its health program. According to the World Health Organization, 56.9 million deaths were recorded worldwide in 2016 (WHO 2018). Human Immunodeficiency Virus (HIV) has been a major cause of death, particularly in developing countries since the first epidemic broke out in the USA in the 1980s (CDC 2001). The prevalence of HIV mortality was ranked as the $39^{\text {th }}$ cause of death in 1995 and $11^{\text {th }}$ in
2015 (Wang et al. 2016). While in recent years, the burden caused by the disease is decreasing, it remains an important area of study.

Since the outbreak of the epidemic, more than 70 million people have been infected and about 35 million people have died from HIV/AIDS (Lima 2015; UNAIDS 2016). Asia is the second largest region next to sub-Sahara Africa. Between years 2005 and 2012, HIV mortality in Asia dropped from 2.3 million to 1.6 million (Ishikawa et al. 2016; Zayeri 2016). The HIV mortality decreased from 
1.8 million in year 2005 to 1.2 million in 2015 (Wang et al. 2016).

Thailand had the highest HIV prevalence in Southeast Asia in 2014. In year 2016, there were approximately 450,000 people living with HIV; with 6,400 new cases and 16,000 deaths related to HIV/AIDS (Chaivooth et al. 2017). Among Asian countries, Thailand was the first country to propose Antiretroviral Therapy (ART). In year 2000, the National Health Security Office (NHSO) initiated a free trial program called National Access to Antiretroviral Therapy Program (NAPHA). Due to the increase of ART coverage in Thailand, HIV mortality was reduced from $16 \%$ in 2008 to $3 \%$ in 2014; for those who started ART (Chasombat et al. 2009, 2006).

Although several studies have been conducted to recently assess HIV mortality in Thailand, most of these studies are sourced from a single database (Fregonese et al. 2012; Jongsthapongpanth et al. 2010; Quan et al. 2007). There is a lack of reliable statistics from the vital registration system for determining the cause-of-death in Thailand (Porapakkham et al. 2010). Data from a single source could not provide sufficient and reliable information (Vapattanawong \& Prasartkul 2011). Therefore, it is essential to use a linked database in order to obtain most accurate outcome. Our study linked three data sources obtained from the Bureau of Registration and Administration (BORA) and the National Health Security Office of Thailand.

This study aimed to investigate HIV mortality in Thailand between 2014 and 2015 by age group and gender. Such information assists policy makers to examine the burden of disease and to provide information for the Joint United Nations Programme on HIV/AIDS (UNAIDS) to meet the goal of reducing HIV related death.

\section{Materials AND Methods}

\section{DATA SOURCES AND MANAGEMENT}

A retrospective study was conducted to predict HIV mortality for years 2014 and 2015. Data were collected from the National AIDS Program (NAP), the Bureau of Registration and Administration (BORA) and the National Health Security Office (NHSO) of Thailand. The data sources were from vital registry inpatient registration and antiretroviral therapy registration. Deaths diagnosed as HIV was obtained from vital registry (VR), were linked to the NAP and inpatient (IP) database. NHSO used individual unique identification numbers consisting of 13 characters to avoid overlapping while linking the three datasets together (Naiwatanakul et al. 2016). The Antiretroviral therapy registration data set consist of HIV patient history following ART therapy in each hospital and health facilities across Thailand obtained by NAP. As Thai law requires death to be reported within $24 \mathrm{~h}$, an electronic database was created in 2008 to link death registry with the NHSO of Thailand enabling health professionals to complete online forms for each visit. In addition, this program provides free ART treatment according to national guidelines for every HIV/AIDS infected Thai patients across regions in Thailand (Chaivooth et al. 2017).

A total number of 881,598 deaths were recorded for the years 2014 to 2015 with 435,634 deaths in 2014 and 445,964 deaths in 2015. Of these, 23,243 deaths (2.6\%) were recorded from HIV/AIDS, which were confirmed by the International Classification of Disease Version 10 (ICD10 ) in NAP database. Population data for the study period from the Ministry of Public Health (MOPH) were used as denominators.

Information from the data included age, gender (male/ female), year of death (2014/2015), receipt of ART (yes/ no), NAP participation (yes/no), place of death (inside/ outside hospital) and number of HIV deaths. Age was categorized into eight age groups as follows: 0-29, 30-34, 35-39, 40-44, 45-49, 50-54, 55-59 and 60+.

\section{STATISTICAL ANALYSIS}

Descriptive analysis was performed to describe the distribution for each variable. HIV mortality rates were calculated per 100,000 population separated by age, gender and year of death. To manage the interaction effect between age group and gender, we combined these two variables together to form a new variable called gender-age group with 16 categories ( 8 age groups $\times 2$ gender groups). For statistical modeling, explanatory variables selected for the study were gender-age group and year, with the HIV mortality rate as outcome. Poisson regression was first fitted. However, it assumes that the mean value equals the variance. This assumption was not supported by the data, as a negative binomial model was used to accommodate over-dispersion (Jansakul \& Hinde 2004; Lima et al. 2015). Sum contrast was used to conduct and plot confidence intervals (Tongkumchum \& McNeil 2009). Data management, statistical analysis, and graphical displays were carried out using the R program (R Core Team 2016).

This study has been reviewed by Human Research Ethics in full compliance with the Declaration of Helsinki and the Belmont Report by Prince of Songkla University, Pattani Campus committee.

\section{Results AND Discussion}

There were 11,767 and 11,476 deaths due to HIV/AIDS in 2014 and 2015 accounted for $2.7 \%$ and $2.6 \%$ of all reported deaths. The results obtained from the descriptive analysis of HIV mortality are summarized in Table 1. Males accounted for $65 \%$ of deaths. The highest HIV mortality $(19 \%)$ was recorded in age group 40 to 44 , followed by ages 45-49 (17.8\%), 35-39 (14.5\%), and 50-54 (12.6\%), $60+$ years $(9.9 \%), 0-29(9.1 \%)$, and $30-34$ years $(8.9 \%)$, respectively. The lowest death rate was found in age group $55-59(7.9 \%)$. Of all HIV deaths, $55.8 \%$ were on ART treatment and $61.6 \%$ of deaths occurred inside hospital. In 
addition, from all HIV deaths $91.2 \%$ of them were included in the National AIDS program (NAP). Numbers of HIV deaths in both years were similar.

HIV/AIDS mortality rates per 100,000 populations were calculated by gender-age group and year as shown in Table 2. The highest mortality rate was found in age group 40-49 years in males and age group 40-44 years in females. HIV/AIDS mortality rates in year 2014 and 2015 were 18.6 and 18.1 per 100,000 populations.

The results from the statistical analysis for Poisson and negative binomial models are presented in Figures 1 and 2.

Figure 1 shows plots of residuals after fitting models for HIV mortality data with each regression model. In the Poisson model, the deviance is 77.6 on 15 degrees of freedom with a p-value of $<0.001$. The highly significant p-value shows that the Poisson model fails to fit the data due to over dispersion. The deviance residual plot for the negative binomial model, over dispersion parameter gives the deviance 15.4 degree of freedom which is an acceptable fit for the model with p-value 0.42 .

The coefficients and standard errors of each variable obtained from negative binomial model were converted

TABLE 1. Characteristics, NAP participation and receipt of ART of HIV mortalities

\begin{tabular}{|c|c|c|}
\hline Variables & Number & $\%$ \\
\hline \multicolumn{3}{|l|}{ Gender } \\
\hline Male & 15,126 & 65.0 \\
\hline Female & 8,117 & 35.0 \\
\hline \multicolumn{3}{|c|}{ Age groups (Years) } \\
\hline $0-29$ & 2,118 & 9.1 \\
\hline $30-34$ & 2,076 & 8.9 \\
\hline $35-39$ & 3,393 & 14.5 \\
\hline $40-44$ & 4,417 & 19.0 \\
\hline $45-49$ & 4,140 & 17.8 \\
\hline $50-54$ & 2,937 & 12.6 \\
\hline $55-59$ & 1,841 & 7.9 \\
\hline $60+$ & 2,321 & 9.9 \\
\hline \multicolumn{3}{|l|}{ NAP participation } \\
\hline Yes & 21,207 & 91.2 \\
\hline No & 2,036 & 8.8 \\
\hline \multicolumn{3}{|l|}{ Receipt of ART } \\
\hline Yes & 12,958 & 55.8 \\
\hline No & 10,285 & 44.2 \\
\hline \multicolumn{3}{|l|}{ Place of death } \\
\hline Inside hospital & 14,280 & 61.6 \\
\hline Outside hospital & 8,903 & 38.4 \\
\hline \multicolumn{3}{|l|}{ Year } \\
\hline 2014 & 11,767 & 50.6 \\
\hline 2015 & 11,476 & 49.4 \\
\hline
\end{tabular}

into death rates and their confidence intervals. Then, 95\% confidence interval (CI) plot was created as shown in Figure 2. The horizontal line defines the overall mean of the death rate. The dots aside with the upper and lower bounds based on the CI indicates the death rate. The CI above or below the horizontal line represents groups that are greater than or lower than the overall mean. However, if the CI crossed the horizontal line indicates that there is no evidence corresponding group differs from the mean value. Statistically, the difference between genders was significant, with males having a higher HIV death rate than females. Males aged 40-49 years had the highest death rate when compared with the other age groups. The highest death rate among females was found in age group 40-44 years. Both males and females had the lowest death rate in age group 0-29 years. Death rates between year 2014 and 2015 were not statistically significant different.

\section{HIV/AIDS MORTALITY RATE IN THAILAND}

Overall, HIV mortality in both years was $2.6 \%$, representing 18.3 deaths per 100,000 populations. Mortality rates in Thailand fell after the introduction of ART in 1997 but had

TABLE 2 . HIV mortality rates per 100,000 population by gender-age group and year

\begin{tabular}{|c|c|c|}
\hline Variables & Number of deaths & Mortality rate per 100,000 \\
\hline \multicolumn{3}{|l|}{ Male } \\
\hline $0-29$ & 1,281 & 5.1 \\
\hline $30-34$ & 1,356 & 27.1 \\
\hline $35-39$ & 2,117 & 40.8 \\
\hline $40-44$ & 2,871 & 55.6 \\
\hline $45-49$ & 2,783 & 55.6 \\
\hline $50-54$ & 1,980 & 43.8 \\
\hline $55-59$ & 1,233 & 34.3 \\
\hline $60+$ & 1,505 & 18.3 \\
\hline \multicolumn{3}{|l|}{ Female } \\
\hline $0-29$ & 837 & 3.4 \\
\hline $30-34$ & 720 & 14.5 \\
\hline $35-39$ & 1,276 & 24.3 \\
\hline $40-44$ & 1,546 & 28.6 \\
\hline $45-49$ & 1,357 & 25.1 \\
\hline $50-54$ & 957 & 19.3 \\
\hline $55-59$ & 608 & 15.0 \\
\hline $60+$ & 816 & 7.9 \\
\hline \multicolumn{3}{|l|}{ Year } \\
\hline 2014 & 11,767 & 18.6 \\
\hline 2015 & 11,476 & 18.1 \\
\hline
\end{tabular}


HIV mortality in Thailand 2014 and 2015

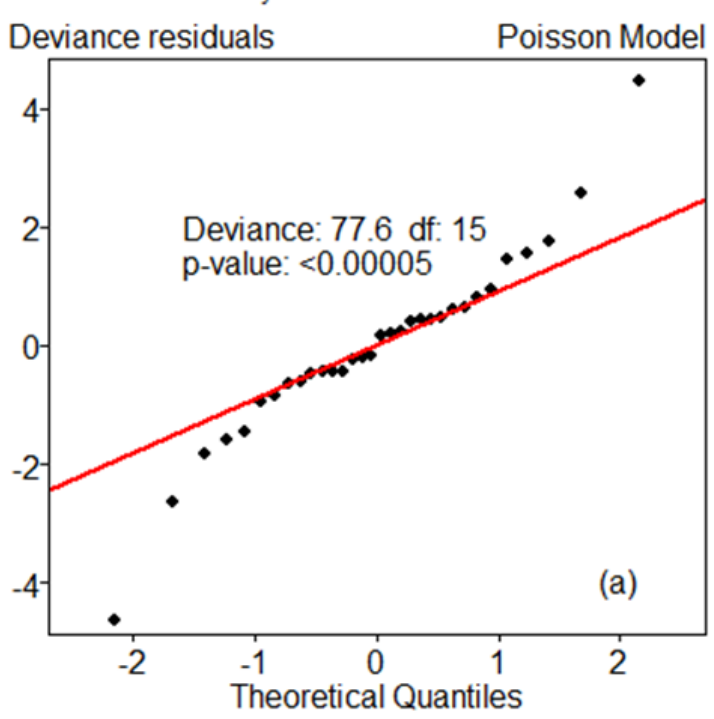

HIV mortality in Thailand 2014 and 2015

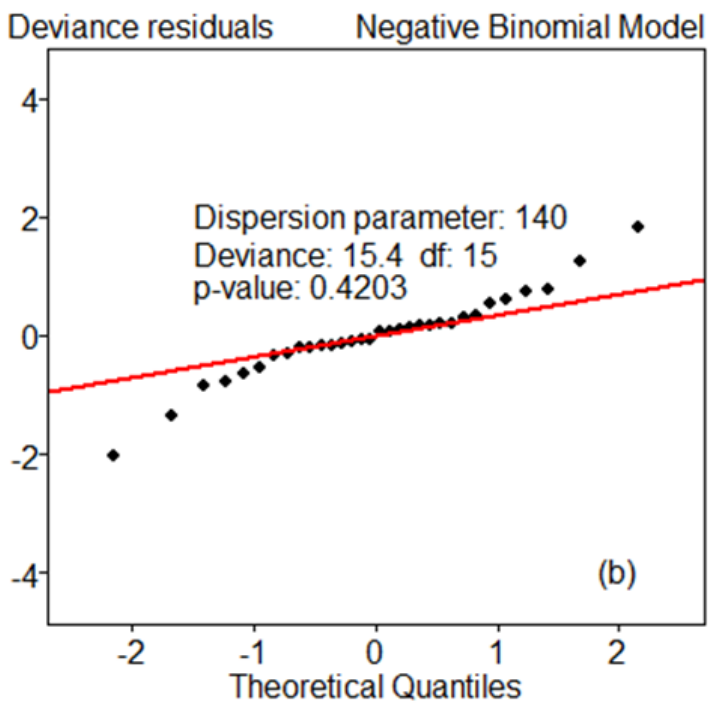

FIGURE 1. Residual plot of Poisson regression model (a), negative binomial model (b)

been continued stable later 2006, and mortality had decreased from $16 \%$ to $3 \%$ in 2014 in 2008 for patients on ART treatment (Chaivooth et al. 2017; Judd et al. 2018). Essentially the declining mortality was evident from 2003 to 2006 that indicated the starting point of universal ART. In addition, this reduction could be due to the institution of the NAP in 2008 to freely enroll all HIV patients on ART (Bundhamcharoen et al. 2011; Chaivooth et al. 2017; Naiwatanakul et al. 2016). In our study, $91 \%$ of HIV deaths enrolled in the NAP and $56 \%$ of HIV deaths received ART. Among 21,207 HIV deaths participated in NAP, 12,958 deaths received ART accounted for $61 \%$. The left $39 \%$ of deaths did not receive ART were in high percentage. It can be indicated that if more patients enrolled on ART, the mortality rate would have been lower than reported. Apart from the NAP, the Thai government has also undertaken different responsive measures to the HIV pandemic and this measure have also caused such reduction in mortality rates (Siraprapasir et al. 2016).

HIV mortality in Thailand is significantly associated with gender-age group. HIV mortality was higher in males across all age groups compared to females and the mortality rate was also higher than the overall mean mortality rate. There was a total HIV death of 15,126 for males over the period and this figure represents a reduction from 26,400 death reported in 2004. The number of deaths in females

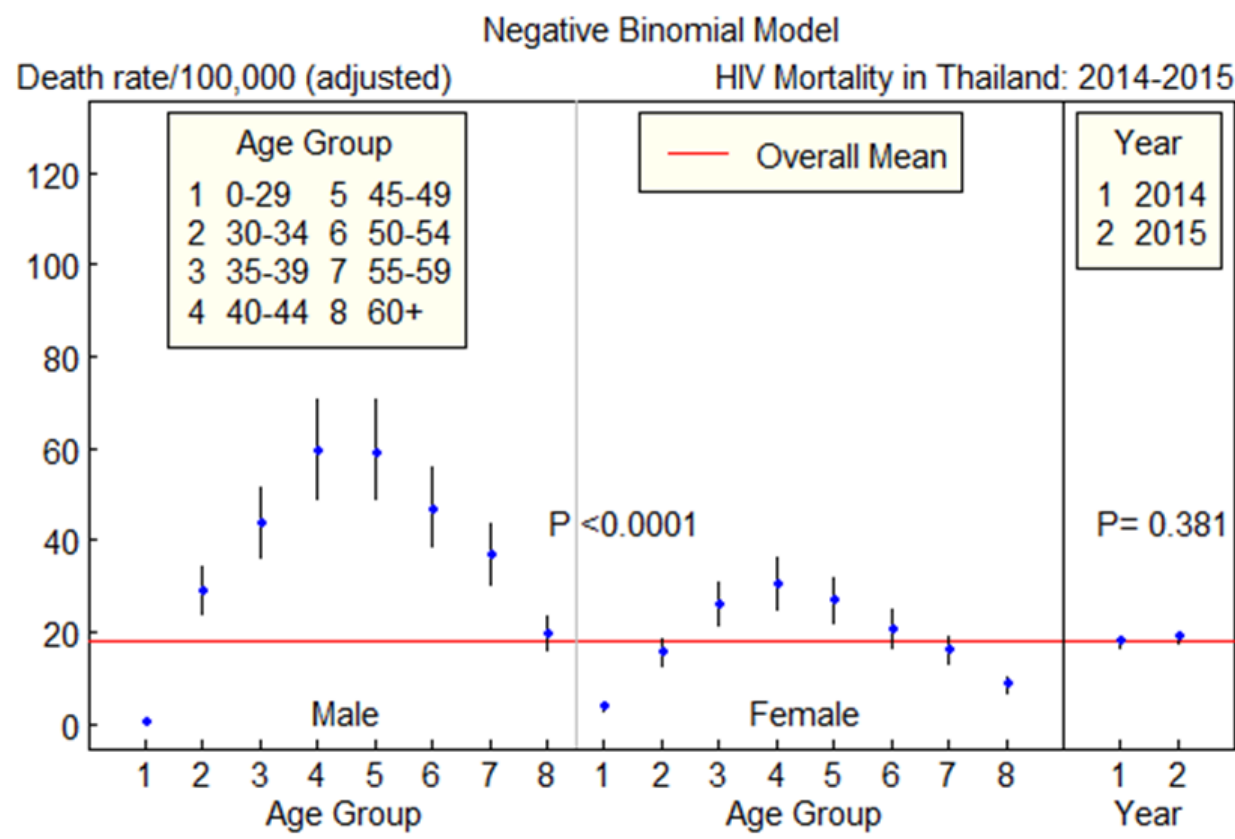

FIGURE $2.95 \%$ CI plot for HIV mortality rates from negative binomial model 
also reduced from 11,000 in 2004 to 8,117 in 2015 (Siraprapasir et al. 2016). Similar findings have been documented in Italy, Thailand and various parts of the world to confirm that higher HIV deaths are recorded in males (Aldaz et al. 2011; Alibhai et al. 2010; Bundhamcharoen et al. 2011; Gonzalez et al. 2011). Globally, the variation between the mortality rates of males and females could be attributed to different factors such as the fact that females are likely to enroll in antiretroviral programs early, especially during pregnancy (Chen et al. 2008). Also, the prevention of Mother-to-Child Transmission (PMTCT) programs gives women access to antiretroviral therapy faster than males and men have poor adherence to treatment than females (Johannessen et al. 2008; Seyoum et al. 2017).

Although there is evidence to show that age was not significantly associated with HIV mortality (Alibhai et al. 2010; Antiretroviral Therapy Cohort Collaboration 2010; Lieb et al. 2002), our study found otherwise. Results from the present study suggest that HIV mortality in Thailand is much dependent on age. The highest death rate was found among males aged 40-49 years and females aged 40-44 years. Our finding indicated that HIV deaths occurred in older age than global deaths reported by Frank et al. (2019) which showed that the highest HIV death rate in year 2017 was found in females aged 30-34 years and in males aged 35-39 years. One unanticipated finding in this study was that no deaths were recorded from HIV for those aged below two years. In our study we used three data base settings for the confirmation of the cause of death (COD). It appears that NAP is successful in preventing mother to child transmission (PMTCT). After a report, in 2016 when Thailand became the first country in Asia to eliminate mother to child transmission reduces maternal and infant morbidity and mortality due to Antenatal Care (ANC) (Ishikawa et al. 2016).

\section{Conclusion}

Despite the relevance of reduction of HIV mortality in Thailand, this study clearly illustrates that HIV mortality rate is dependent on age and gender in Thailand. The study of our result affirmed that $61 \%$ percent of the NAP patients were under ART to prevent the growth of HIV virus. There was a statistical significance in HIV mortality rate where male have higher than females. Males aged 40-49 years and females aged 40-44 years had the highest mortality rate. Therefore, regardless of the pertinence of reduction in the HIV mortality rate in Thailand, the study presented that HIV mortality in Thailand is much dependent on age and gender. Thus, we suggest continued effort is needed to address gender and age difference.

\section{ACKNOWLEDGEMENTS}

We express appreciation to Emeritus Professor Don McNeil for his help on data management, and statistical analysis, the Ministry of Public Health of Thailand and National AIDS Programme (NAP) for generously providing the data, Thailand's Education Hub (TEH-AC) Grant and Graduate School of Prince of Songkla University, Pattani Campus, for financial support and grant.

\section{REFERENCES}

Aldaz, P., Moreno-Iribas, C., Egüés, N., Irisarri, F., Floristan, Y., Sola-Boneta, J. \& Castilla, J. 2011. Mortality by causes in HIV-infected adults: Comparison with the general population. BMC Public Health 11(1): 300.

Alibhai, A., Kipp, W., Saunders, L.D., Senthilselvan, A., Kaler, A., Houston, S. \& Rubaale, T. 2010. Gender-related mortality for HIV-infected patients on highly active antiretroviral therapy (HAART) in rural Uganda. International Journal of Women's Health 2: 45-52.

Antiretroviral Therapy Cohort Collaboration. 2010. Causes of death in HIV-1-infected patients treated with antiretroviral therapy, 1996-2006: Collaborative analysis of 13 HIV cohort studies. Clinical Infectious Diseases 50(10): 13871396.

Bundhamcharoen, K., Odton, P., Phulkerd, S. \& Tangcharoensathien, V. 2011. Burden of disease in Thailand: Changes in health gap between 1999 and 2004. BMC Public Health 11(1): 53.

Centers for Disease Control and Prevention CDC. 2001. HIV and AIDS--United States, 1981-2000. MMWR. Morbidity and Mortality Weekly Report 50(21): 430-434.

Chaivooth, S., Bhakeecheep, S., Ruxrungtham, K., Teeraananchai, S., Kerr, S.J., Teeraratkul, A. \& Phanuphak, N. 2017. The challenges of ending AIDS in Asia: Outcomes of the Thai National AIDS Universal Coverage Programme, 2000-2014. Journal of Virus Eradication 3(4): 192-199.

Chasombat, S., McConnell, M.S., Siangphoe, U., Yuktanont, P., Jirawattanapisal, T., Fox, K. \& Pinyopornpanich, S. 2009. National expansion of antiretroviral treatment in Thailand, 2000-2007: Program scale-up and patient outcomes. JAIDS Journal of Acquired Immune Deficiency Syndromes 50(5): 506-512.

Chasombat, S., Lertpiriyasuwat, C., Thanprasertsuk, S., Suebsaeng, L. \& Lo, Y.R. 2006. The national access to antiretroviral program for PHA (NAPHA) in Thailand. Southeast Asian Journal of Tropical Medicine and Public Health 37(4): 704-715.

Chen, S.C.C., Yu, J.K.L., Harries, A.D., Bong, C.N., KololaDzimadzi, R., Tok, T.S., King, C.C. \& Wang, J.D. 2008. Increased mortality of male adults with AIDS related to poor compliance to antiretroviral therapy in Malawi. Tropical Medicine \& International Health 13(4): 513-519.

Frank, T.D., Carter, A., Jahagirdar, D., Biehl, M.H., DouwesSchultz, D., Larson, S.L. \& Murray, C.J.L. 2019. Global, regional, and national incidence, prevalence, and mortality of HIV, 1980-2017, and forecasts to 2030, for 195 countries and territories: A systematic analysis for the global burden of diseases, injuries, and risk factors study 2017. Lancet HIV 6(12): E831-E859.

Fregonese, F., Collins, I.J., Jourdain, G., LeCoeur, S., Cressey, T.R., Ngo-Giang-Houng, N. \& Lallemant, M. 2012. Predictors of 5-year mortality in HIV-infected adults starting highly active antiretroviral therapy in 
Thailand. JAIDS Journal of Acquired Immune Deficiency Syndromes 60(1): 91-98.

Gonzalez, M.A., Martin, L., Munoz, S. \& Jacobson, J.O. 2011. Patterns, trends and sex differences in HIV/AIDS reported mortality in Latin American countries: 1996-2007. BMC Public Health 11(1): 605.

Ishikawa, N., Newman, L., Taylor, M., Essajee, S., Pendse, R. \& Ghidinelli, M. 2016. Elimination of mother-to-child transmission of HIV and syphilis in Cuba and Thailand. Bulletin of the World Health Organization 94(11): 787.

Jansakul, N. \& Hinde, J.P. 2004. Linear mean-variance negative binomial models for analysis of orange tissue-culture data. Songklanakarin J. Sci. Technol. 26: 683-696.

Johannessen, A., Naman, E., Ngowi, B.J., Sandvik, L., Matee, M.I., Aglen, H.E. \& Bruun, J.N. 2008. Predictors of mortality in HIV-infected patients starting antiretroviral therapy in a rural hospital in Tanzania. BMC Infectious Diseases 8(1): 52.

Jongsthapongpanth, A. \& Bagchi-Sen, S. 2010. Spatial and sex differences in AIDS mortality in Chiang Rai, Thailand. Health \& Place 16(6): 1084-1093.

Judd, A., Chappell, E., Turkova, A., Le Coeur, S., NogueraJulian, A., Goetghebuer, T. \& Collins, I.J. 2018. Longterm trends in mortality and AIDS-defining events after combination ART initiation among children and adolescents with perinatal HIV infection in 17 middle-and high-income countries in Europe and Thailand: A cohort study. PLoS Medicine 15(1): e1002491.

Lieb, S., Brooks, R.G., Hopkins, R.S., Thompson, D., Crockett, L.K., Liberti, T. \& McLaughlin, G. 2002. Predicting death from HIV/AIDS: A case-control study from Florida public HIV/AIDS clinics. Journal of Acquired Immune Deficiency Syndromes 30(3): 351-358.

Lima, V.D., Lourenço, L., Yip, B., Hogg, R.S., Phillips, P. \& Montaner, J.S. 2015. AIDS incidence and AIDS-related mortality in British Columbia, Canada, between 1981 and 2013: A retrospective study. The Lancet HIV 2(3): e92-e97.

Naiwatanakul, T., Voramongkol, N., Punsuwan, N., Lolekha, R., Gass, R., Thaisri, H. \& Bhakeecheep, S. 2016. Uptake of early infant diagnosis in Thailand's national program for preventing mother-to-child HIV transmission and linkage to care, 2008-2011. Journal of the International AIDS Society 19(1): 20511.

Porapakkham, Y., Rao, C., Pattaraarchachai, J., Polprasert, W., Vos, T., Adair, T. \& Lopez, A.D. 2010. Estimated causes of death in Thailand, 2005: Implications for health policy. Population Health Metrics 8(1): 14.

Quan, V.M., Vongchak, T., Jittiwutikarn, J., Kawichai, S., Srirak, N., Wiboonnatakul, K. \& Celentano, D.D. 2007. Predictors of mortality among injecting and non-injecting HIV-negative drug users in Northern Thailand. Addiction 102(3): 441-446.

R Core Team. 2016. R: A language and environment for statistical computing. R Foundation for Statistical
Computing, Vienna, Austria. https://edit4020.wordpress. com/2016/06/21/r-a-language-and-environment-forstatistical-computing/.

Seyoum, D., Degryse, J.M., Kifle, Y., Taye, A., Tadesse, M., Birlie, B. \& Speybroeck, N. 2017. Risk factors for mortality among adult HIV/AIDS patients following antiretroviral therapy in Southwestern Ethiopia: An assessment through survival models. International Journal of Environmental Research and Public Health 14(3): 296.

Siraprapasiri, T., Ongwangdee, S., Benjarattanaporn, P., Peerapatanapokin, W. \& Sharma, M. 2016. The impact of Thailand's public health response to the HIV epidemic 1984-2015: Understanding the ingredients of success. Journal of Virus Eradication 2(4): 7-14.

Tongkumchum, P. \& McNeil, D. 2009. Confidence intervals using contrasts for regression model. Songklanakarin Journal of Science \& Technology 31(2): 151-156.

UNAIDS. 2016. Global AIDS update 2016. World Health Organization.

Vapattanawong, P. \& Prasartkul, P. 2011. Under-registration of deaths in Thailand in 2005-2006: Results of crossmatching data from two sources. Bulletin of the World Health Organization 89: 806-812.

Wang, H., Wolock, T.M., Carter, A., Nguyen, G., Kyu, H.H., Gakidou, E. \& Coates, M.M. 2016. Estimates of global, regional, and national incidence, prevalence, and mortality of HIV, 1980-2015: The global burden of disease study 2015. The Lancet HIV 3(8): e361-e387.

World Health Organization. 2018. The Top 10 Causes of Death. https://www.who.int/news-room/fact-sheets/detail/thetop-10-causes-of-death.

Zayeri, F., Ghane, E.T. \& Borumandnia, N. 2016. Assessing the trend of HIV/AIDS mortality rate in Asia and North Africa: An application of latent growth models. Epidemiology \& Infection 144(3): 548-555.

Hiwot D. Tulu*, Apiradee Lim \& Arinda Ma-a-Lee Department of Mathematics and Computer Science Faculty of Science and Technology

Prince of Songkla University

Pattani Campus

Thailand

Kanitta Bundhamcharoen \& Nuttapat Makka

International Health Policy Program

Ministry of Public Health

Nonthaburi

Thailand

*Corresponding author; email: hiwatihiwaye@gmail.com

Received: 22 March 2019

Accepted: 22 October 2019 